\title{
Postharvest Development of 'Candidatus Liberibacter solanacearum' in Late-Season Infected Potato Tubers under Commercial Storage Conditions
}

\author{
Arash Rashed, ${ }^{\dagger}$ Department of Entomology, Plant Pathology and Nematology, University of Idaho, Aberdeen R\&E Center, Aberdeen 83210; \\ Nora Olsen, Department of Plant Sciences, University of Idaho, Kimberly R\&E Center, Kimberly 83341; Christopher M. Wallis, United \\ States Department of Agriculture-Agricultural Research Service San Joaquin Valley Agricultural Sciences Center, Crop Diseases, Pests \\ and Genetics Research Unit, Parlier, CA 93648; Li Paetzold, Texas A\&M AgriLife Research and Extension Center, Amarillo 79106; Lynn \\ Woodell, Department of Plant Sciences, University of Idaho, Kimberly R\&E Center; Mahnaz Rashidi, Department of Entomology, Plant \\ Pathology and Nematology, University of Idaho, Aberdeen R\&E Center; and Fekede Workneh and Charles M. Rush, Texas A\&M AgriLife \\ Research and Extension Center
}

\begin{abstract}
Zebra chip (ZC) disease of potato is associated with the putative pathogen 'Candidatus Liberibacter solanacearum', which is transmitted by the potato psyllid Bactericera cockerelli (Hem., Triozidae). The present study was initiated to investigate ' $C a$. L. solanacearum' development during and following typical commercial storage practices. Using bacteriliferous psyllids, Russet Norkotah potato tubers were infested in field cages 14,10 , and 4 days before harvest. Changes in ' $\mathrm{Ca}$. L. solanacearum' detection rate, ' $\mathrm{Ca}$. L. solanacearum' titer, and concentrations of phenolic compounds were documented throughout storage. ' $\mathrm{Ca}$. L. solanacearum' titer continued to increase during storage. Although significant increases

in the frequency of ' $\mathrm{Ca}$. L. solanacearum' detection were observed in all infestation treatments, the impact of ' $\mathrm{Ca}$. L. solanacearum' infection on tuber quality remained comparatively low in plants infected 4 days before harvest, because the majority of the tubers remained asymptomatic. Minimizing storage and retail chain movement durations would help to limit ' $\mathrm{Ca}$. L. solanacearum' impact on tuber quality in tubers infected 14 and 10 days before harvest. This study also demonstrated that ' $\mathrm{Ca}$. L. solanacearum' can relocate from a newly infected leaf to a tuber in as little as 4 days. Psyllid management is recommended until at least 4 days before green harvest, when psyllid pressure is high in fields in which tubers are destined for commercial storage.
\end{abstract}

Zebra chip (ZC) has been negatively affecting the potato industry in the Americas for nearly two decades. The discovery of the putative etiological agent of ZC, 'Candidatus Liberibacter solanacearum' (Liefting et al. 2008; Lin et al. 2011), and its vector, the potato psyllid Bactericera cockerelli Sulc (Hem., Triozidae) (Hansen et al. 2008), was a significant breakthrough, setting the stage for new avenues of research. Initially, the most severely affected production regions were those dedicated to potato production for chipping purposes (Goolsby et al. 2007; Secor and Rivera-Varas 2004; Wen et al. 2009), where tubers are processed soon after harvest. As such, studies on Liberibacter-host plant interactions predominantly focused on ' $\mathrm{Ca}$. L. solanacearum' spread and ZC development during the growing season (Buchman et al. 2011, 2012; Haapalainen 2014; Henne et al. 2010; Rashed et al. 2014; Teresani et al. 2014) and its impact on the physiological variables that could influence tuber frying quality at harvest (Navarre et al. 2009; Rashed et al. 2013; Wallis et al. 2015). However, following the appearance of ' $\mathrm{Ca}$. L. solanacearum' in the Pacific Northwest (Crosslin et al. 2012; Hamm et al. 2011; Nolte et al. 2011), the most prominent potato-growing region of the United States, questions were raised about the potential impact of other common potato production practices such as vine-kill and storage on ZC development (Rush et al. 2015).

Following inoculation by its potato psyllid vector, ' $C a$. L. solanacearum' spreads throughout plant tissues via phloem sap (Levy et al.

\section{${ }^{\dagger}$ Corresponding author: A. Rashed; E-mail: arashed@uidaho.edu}

The United States Department of Agriculture (USDA) Specialty Crop Research Initiative (number 2009-511-20176), USDA National Institute for Food and Agriculture Hatch-IDA01506, and TASC Program (number 2013-09) provided funding for this work.

Mention of trade names or commercial products in this publication is solely for the purpose of providing specific information and does not imply recommendation or endorsement by the U.S. Department of Agriculture. USDA is an equal opportunity provider and employer.

Accepted for publication 21 September 2017.

C 2018 The American Phytopathological Society
2011). Foliar symptoms appear within 3 to 4 weeks of infection (Rashed et al. 2014) and typically include stunting, chlorosis, shortened internodes, formation of aerial tubers and axillary buds, leaf scorch, and browning of the vascular system (Secor et al. 2009; Wallis et al. 2015). Although the foliar symptoms may resemble those of other potato disorders (Munyaneza 2012; Secor et al. 2009), diagnostic symptoms of ZC are expressed in the tuber tissue as brown discoloration of vascular rings and medullary rays (Secor et al. 2009). This defect in freshly cut tubers is associated with increased polyphenol oxidase activity levels, resulting from shifts in the levels of phenolic compounds (Wallis et al. 2012). The pronounced darkening of fried ZC-affected potato tubers, however, has been linked primarily to elevated levels of reducing sugars and shifts in some amino acid concentrations (Navarre et al. 2009; Rashed et al. 2013; Wallis et al. 2012). Tuber symptoms may appear as early as 2 weeks after infection and the severity of ZC symptoms depends on the duration of infection (Buchman et al. 2012; Rashed et al. 2014). Although ZC symptoms in late-infected tubers ( $<2$ weeks before harvest) may not yet be expressed at harvest, the early shifts in biochemical properties, which may be initiated soon after pathogen arrival into the tissue (Rashed et al. 2013), could continue to affect product quality as ' $\mathrm{Ca}$. L. solanacearum' continues to develop postharvest (Rashed et al. 2015). To date, however, no studies have been conducted to evaluate $\mathrm{ZC}$ development under commercial storage conditions, where tubers are exposed to varying temperatures to minimize postharvest quality loss. This is of particular importance in the production areas such as the Pacific Northwest where psyllid infestations may occur later in the growing season and infections may remain undetected at harvest, and where the majority of harvested tubers are stored for extended periods of time before marketing and eventual processing (Rush et al. 2015).

The primary objective of the present study was to quantify ' $\mathrm{Ca}$. L. solanacearum' development in late-season-infected potato tubers stored under standard commercial storage conditions (Kleinkopf and Olsen 2003) and, through a poststorage step, simulating retail chain movement. Changes in phenolic compounds known to be associated with symptoms in fresh tuber tissue (Rashed et al. 2013) were quantified to detect ZC symptom progress during the process, and were compared among tubers infested with the potato psyllid vectors 
14,10 , or 4 days before harvest (DBH) at the end of storage. Relationships between ' $\mathrm{Ca}$. L. solanacearum' titer, phenolic concentrations, and symptom severity were investigated after storage. Identifying storage steps that may promote ' $\mathrm{Ca}$. L. solanacearum' development is essential in developing postharvest practices that will minimize ' $\mathrm{Ca}$. L. solanacearum' impact on product quality prior to marketing and processing.

\section{Materials and Methods}

Plant infestations. Field experiments were conducted at the United States Department of Agriculture-Agricultural Research Service (USDA-ARS) Conservation Production Research Laboratory and Texas A\&M AgriLife Vegetable Production Field Lab, Bushland, TX, in 2013 and 2014. The field site consisted of a 14-ha, semicircle-shaped field, irrigated with a Valley center pivot irrigation system. In both years of this study, hard red winter wheat preceded the potato crop. Soil type was a Pullman silty clay loam. Ammonium nitrate $(27.5 \mathrm{~kg} / \mathrm{ha})$ was spread and then the field was bedded with rows at 76-cm spacing, following center-pivot wheel tracks to reduce water and wind erosion. A preplant herbicide was applied and incorporated into the soil with $1.3 \mathrm{~cm}$ of irrigation. During the season, beginning approximately 1 week after emergence and continuing until 2 weeks before harvest, the crop was irrigated as needed, usually with $6.3 \mathrm{~cm}$ of irrigation each week. No pesticides were applied. At harvest, tubers from infested plants were dug by hand.

In both years, certified Russet Norkotah seed potato pieces (of either second or third generation) provided by Barrett Produce Company Inc. (Muleshoe, TX) were planted by a four-row planter in April on the $76-\mathrm{cm}$ beds. Tent-shaped mesh cages, approximately 100 by 100 by $80 \mathrm{~cm}$ (width by depth by height), made of Sungaurd II fiberglass rods (Geoteck Inc., Stewartville, MN) and netting 4750 mesh (U.S. Global Resources, Seattle, WA), were used to cover plants prior to emergence. Following emergence, plants were thinned such that there were six plants per cage, three on each row inside the cage, in 2013, and four plants per cage, one at each corner of the cage, in 2014, about $60 \mathrm{~cm}$ apart.

To inoculate the plants, six potato psyllids from a bacteriliferous greenhouse colony were released at the base of the individual plants within each cage. The bacteriliferous psyllid colonies were known to have a mixed ' $C a$. L. solanacearum' A+B haplotype (Wen et al. 2012). The potato psyllid vectors were of the central haplotype (Swisher et al. 2012) and reared on infected potato plants (variety FL1867) in a bugdorm cage ( 60 by 60 by $60 \mathrm{~cm}$; BioQuip Products, Rancho Dominguez, CA) for several generations prior to infestation. The psyllids were originally collected by Dr. J. Munyaneza from commercial fields in Texas. ' $\mathrm{Ca}$. L. solanacearum' and vector haplotype were determined following Wen et al. (2012) and Swisher et al. (2012), respectively, before each year's field study.
Three different infestation treatments were included in the field studies: 14,10 , and 4 DBH. In 2013, each of the infestation treatments consisted of two cages with 6 plants planted in each cage (total of 12 plants per treatment). In 2014, each of the infestation treatments included 3 cages, each planted with 4 plants (total of 12 plants per infestation treatment). This resulted in a total of 36 infested plants per year. The experiment was arranged in a randomized complete block design. Cages were approximately $3 \mathrm{~m}$ apart along the two rows covered by each cage. In each year, one additional cage per treatment remained uninfested (noninfected control). Potato tubers were harvested (green harvest) from individual plants in August, and a 100-mg subsample of tissue was taken from the stolon attachment area on each of three to four randomly selected tubers (in a few cases less than three, due to limited number of tubers) from each plant and used for ' $\mathrm{Ca}$. L. solanacearum' quantification (quantitative polymerase chain reaction [qPCR], see below). Tubers were then shipped overnight to the University of Idaho Potato Storage Research Facility, Kimberly, for storage. The three steps of storage included (i) wound healing at $13^{\circ} \mathrm{C}$ ( 3 weeks), (ii) temperature ramp down to $7.2^{\circ} \mathrm{C}$ at $0.3^{\circ} \mathrm{C} /$ day (approximately 3 weeks), and (iii) holding at $7.2^{\circ} \mathrm{C}$ for 8 to 9 weeks. Following the 9-week holding period, tubers were placed at $13^{\circ} \mathrm{C}$ for 4 weeks to simulate retail chain movement (Fig. 1). Relative humidity was maintained at $95 \%$ during the different stages of storage.

Using Harris uni-core tissue samplers (Ted Pella, Inc., Redding, CA), individual tubers ( 2 to 4 tubers/plant; 212 total, excluding noninfested controls) from which tissue samples were collected at harvest were sampled at each of the four steps described above. The core tissue sampler was immersed in alcohol and thoroughly flamed between samplings. At each sampling, approximately $100 \mathrm{mg}$ of tissue was removed from the stolon attachment end (basal end) of each tuber for ' $C a$. L. solanacearum' quantification. The same tubers were sampled at harvest and throughout each stage of storage from close proximity of the initial sampling. Additional $150-\mathrm{mg}$ tissue samples were removed at the end of the wound healing and storage periods for phenolic compound analyses. Samples were shipped, overnight (on ice), to the USDA-ARS San Joaquin Valley Agricultural Sciences Center, Parlier, CA (SJVASC).

' $\mathrm{Ca}$. L. solanacearum' DNA extraction and quantification. DNA extractions and quantifications were performed at the Texas A\&M AgriLife Research and Extension in Bushland, following a slightly modified version of DNeasy Plant Mini Kit (Qiagen Inc., Germantown, MD) protocol. Tissue samples were dipped in liquid nitrogen and ground in a homogenizer. Ground samples were incubated at $65^{\circ} \mathrm{C}$ for $15 \mathrm{~min}$ after adding the first set of buffers.

Using an Applied Biosystems 7500 real-time PCR machine (TaqMan probe) and comparative cycle threshold $(\mathrm{Ct})$ method $(\Delta \Delta \mathrm{Ct}),{ }^{\prime} \mathrm{C} a$. $\mathrm{L}$. solanacearum' was quantified in relation to a calibrator and an endogenous 18s RNA control (VIC/MGB probe, primer limited; Applied Biosystems Foster City, CA) (Rashed et al. 2013). The

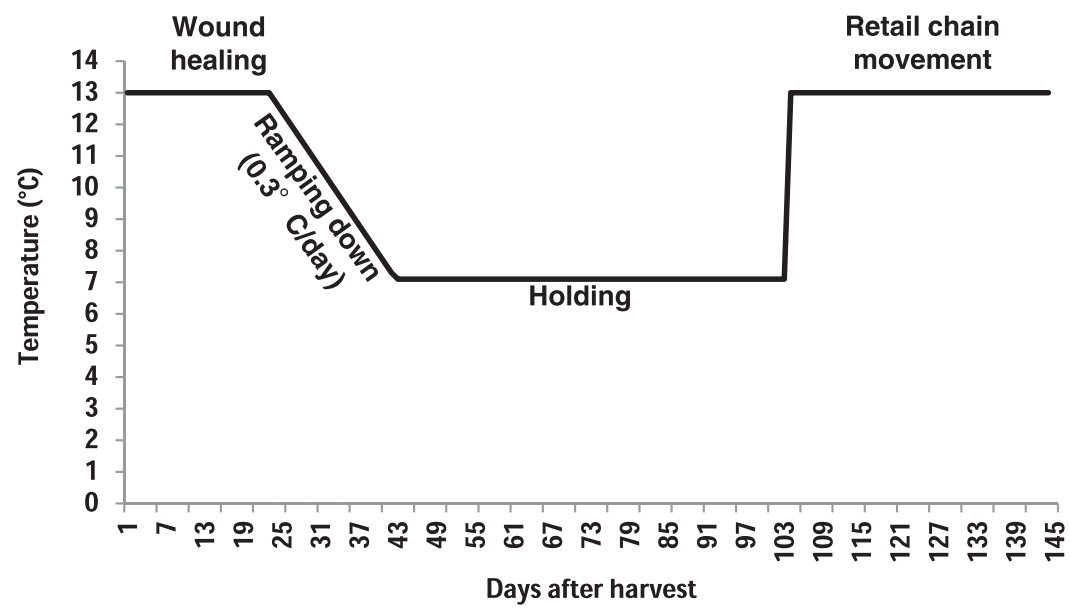

Fig. 1. Schematic representation of the storage process stages and poststorage retail chain movement. 
reaction mix consisted of TaqMan Universal Master Mix (Applied Biosystems), $0.3 \mu \mathrm{M}$ forward primer $\mathrm{LsoF}$ ( $\mathrm{Li}$ et al. 2009), $0.3 \mu \mathrm{M}$ reverse primer $\mathrm{HLBr}$ (Li et al. 2006), and $0.25 \mu \mathrm{M}$ HLBp TaqMan probe ( $\mathrm{Li}$ et al. 2006). Thermal cycling parameters were those recommended by the master-mix reagent kit manufacturer and included holding temperature of $95^{\circ} \mathrm{C}(20 \mathrm{~s})$ and 40 cycles of denaturing at $95^{\circ} \mathrm{C}$ $(1 \mathrm{~s})$ and annealing at $60^{\circ} \mathrm{C}(20 \mathrm{~s})$. Samples with $\mathrm{Ct}$ values greater than 36.99 were deemed negative for ' $\mathrm{Ca}$. L. solanacearum'.

Symptom severity evaluations. Severity of ZC symptoms was evaluated at the end of storage. Longitudinal slices were prepared and the extent of ZC-associated discoloration across the section was scored on a scale of 1 to 3 , with 1 expressing no ZC, 2 expressing moderate symptoms, and 3 expressing severe ZC symptoms (Fig. 2).

Characterization of the phenolic compounds. Analyses were performed at the SJVASC on the tubers harvested in the 2013 season. One aliquot of at least $50 \mathrm{mg}$ was prepared for each of the sampled tubers. The aliquot was extracted over $48 \mathrm{~h}$ at $4^{\circ} \mathrm{C}$ in methanol $(1: 10[\mathrm{wt} / \mathrm{vol}])$ (e.g., $50 \mathrm{mg}$ of tuber tissue extracted in $500 \mathrm{ml}$ of methanol). For quantification of phenolic compounds, a Shimadzu high-performance liquid chromatograph with a mass spectrometer was used for peak identification, as described by Wallis et al. (2012) and Rashed et al. (2013).

In total, 10 phenolic compounds, including protocatechuic acid hexocide, several derivatives of flavanol glucoside, flavanol methyl ester glucoside, two chlorogenic acids, and two cryptochlorogenic derivatives, were characterized.

Statistical analyses. Binary logistic regression was used to compare the probability of ' $\mathrm{Ca}$. L. solanacearum' detection success among the three infestation dates, with year also included as a factor.

Generalized linear mixed model (GLMM) with a log link function was used to compare variations in ' $\mathrm{Ca}$. L. solanacearum' titer across infestation treatments over time. Sampling time was included as the repeated measure. Year, infestation treatment, year-infestation treatment interaction, and plant (random factor) were initially included as predictor variables. Because no significant year-infestation treatment interaction was detected $(P=0.213)$, this term was excluded from the final model. In all analyses, plant was removed in a stepwise approach if its effect was nonsignificant $(P>0.05)$.

GLMM with a log link function was also used to analyze changes in ' $\mathrm{Ca}$. L. solanacearum' titer during every storage step. Relative changes of ' $\mathrm{Ca}$. L. solanacearum' titer (' $\mathrm{Ca}$. L. solanacearum' $\left.\left[\chi, \chi_{\text {ref }}\right]\right)$ within every step of storage was calculated by subtracting ' $C a$. L. solanacearum' titer at the start of every step, also referred to as reference ' $C a$. L. solanacearum' (' $C a$. L. solanacearum' $\chi_{\text {ref }}$ ) from titer levels estimated at the end of the step (' $\mathrm{Ca}$. L. solanacearum' $\chi$ ) and dividing it by ' $\mathrm{Ca}$. L. solanacearum' ( $\left.\chi_{\text {ref }}\right)$, where 'Ca. L. solanacearum' $\left(\chi, \chi_{\text {ref }}\right)=\left[{ }^{\prime} C a\right.$. L. solanacearum' $(\chi)-$ 'Ca. L. solanacearum' $\left.\left(\chi_{\mathrm{ref}}\right)\right] /{ }^{\circ} \mathrm{Ca}$. L. solanacearum' $\left(\chi_{\mathrm{ref}}\right)$. Prior to this calculation, a value of 1.5 was added to all ' $\mathrm{Ca}$. L. solanacearum' titers and to render all values greater than zero. Noninfested controls were excluded from ' $C a$. L. solanacearum' analysis to avoid bias in conclusions.

Nonparametric Kruskal-Wallis was used to compare poststorage symptom severities among infestation treatments. Mann-Whitney was initially used to examine the presence of year effect on symptom expression between the 2 years. Spearman ranked $\left(r_{s}\right)$ was used to evaluate relationships between symptom severities and ' $\mathrm{C} a$. L. solanacearum' titer, and phenolic concentrations at the end of storage.

Multivariate analysis of variance (MANCOVA) was used to analyze phenolic compound concentrations in infected and noninfected controls. Infestation time and plant were the predictor variables. Relative changes in phenolic activity [phenol $\left.\left(\chi, \chi_{\text {ref }}\right)\right]$ at the end of cold storage were quantified by subtracting concentrations at the start of the temperature ramping down $\left[\mathrm{phenol}\left(\chi_{\text {ref }}\right)\right]$ from concentrations following cold storage [phenol $(\chi)]$ and dividing the outcome by the starting concentration $\left[\right.$ phenol $\left.\left(\chi_{\text {ref }}\right)\right]$, where phenol $\left(\chi, \chi_{\text {ref }}\right)=[$ phenol $(\chi)-$ phenol $\left.\left(\chi_{\text {ref }}\right)\right] /$ phenol $\left(\chi_{\text {ref }}\right)$. A fixed value was added to phenol $\left(\chi, \chi_{\text {ref }}\right)$ to render all values positive for log-transformation. Bonferroni correction was applied to all least significant difference (LSD) pairwise comparisons, to reduce the risk of type I error. Pearson $(r)$ correlation was used to evaluate relationships between changes in phenolic compounds [phenol $\left.\left(\chi, \chi_{\text {ref }}\right)\right]$ and ' $C a$. L. solanacearum' ( $\left.\chi, \chi_{\text {ref }}\right)$.

All statistical analyses were performed in IBM-SPSS (version 22.0; IBM, Armonk, NY).

\section{Results}

Frequency of ' $\mathrm{Ca}$. L. solanacearum' detection in relation to time of psyllid infestation. 'Ca. L. solanacearum' detection at harvest. Probability of successful ' $\mathrm{Ca}$. L. solanacearum' detection at harvest was significantly affected by both the time of infestation by the

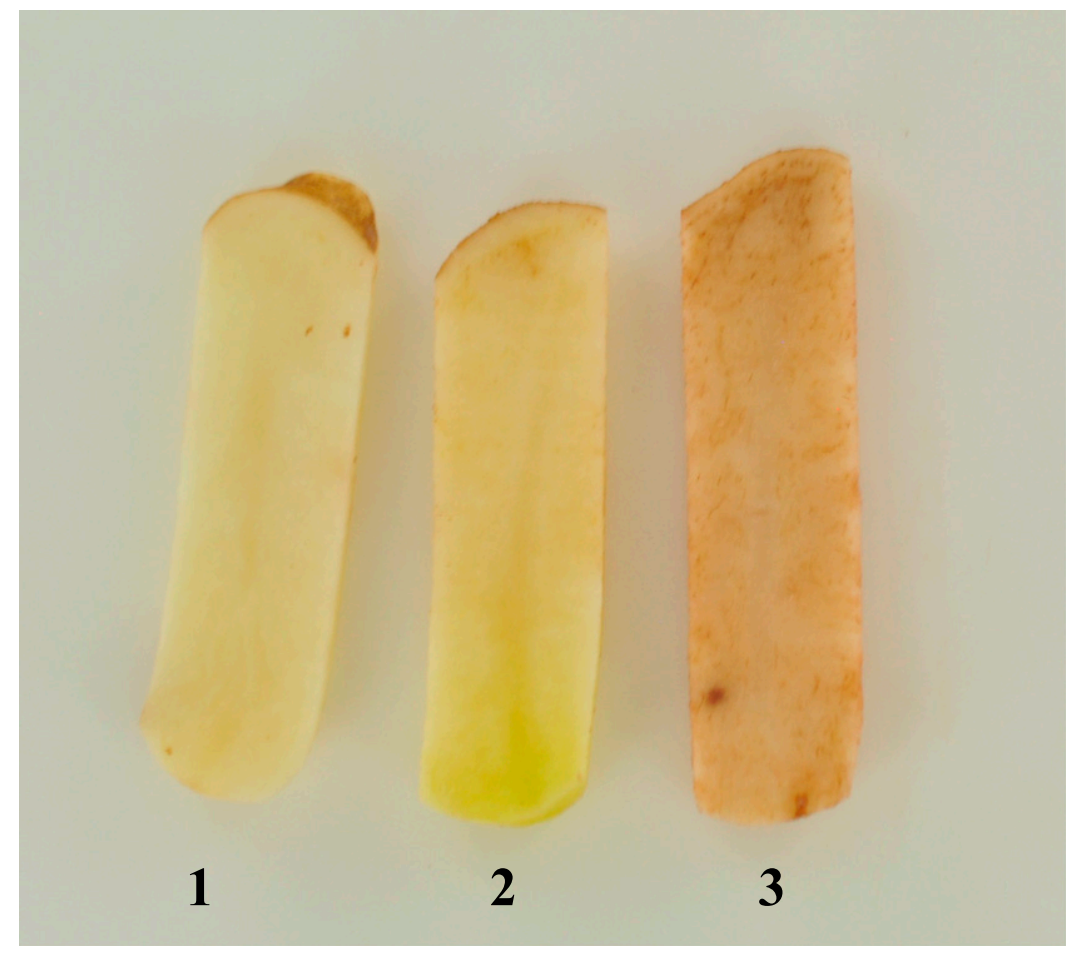

Fig. 2. Zebra chip (ZC) severity scale used to characterize Russet Burbank tubers poststorage, with 1 representing no symptoms and 3 representing severe ZC. 
potato psyllids (Wald, $\left.\chi_{2}^{2}=27.06, P<0.001\right)$ and year $\left(\chi_{1}^{2}=30.12\right.$, $P<0.001)$. None of the tubers from the 4-DBH treatment tested positive for ' $\mathrm{Ca}$. L. solanacearum' at harvest, and only a small percentage of tubers in the 10-DBH treatment tested positive $(2013=5.13 \%$ and $2014=0 \%$ ). However, in the 14-DBH treatment, 82.2 and $13.3 \%$ of the tubers tested positive at harvest in 2013 and 2014, respectively (Fig. 3A and B). Although ' $\mathrm{Ca}$. L. solanacearum' detection rate was statistically significantly higher at 14 than at $10 \mathrm{DBH}$ in $2013\left(\chi_{1}^{2}=\right.$ $29.15, P<0.001$ ), only descriptive comparisons are presented for 2014 results, because none of the tubers from the 10-DBH treatment tested positive for ' $\mathrm{Ca}$. L. solanacearum' at harvest.

'Ca. L. solanacearum' detection poststorage. The frequency of ' $C a$. L. solanacearum' detection at the end of the simulated retail chain movement was influenced by both infestation treatment and year (time of infestation: $\chi_{2}^{2}=39.12, P<0.001$; year: $\chi_{1}^{2}=21.88$, $P<0.001)$. The observed variation was primarily driven by the last infestation treatment (4 DBH), because no significant difference was observed in the percentage of the tubers that tested positive for ' $C a$. L. solanacearum' between the 10- and 14-DBH treatments $\left(\chi_{1}^{2}=1.13, P=0.286\right)$ (Fig. $3 \mathrm{~A}$ and B).

Overall, the percentage of samples that tested positive for ' $\mathrm{Ca}$. L. solanacearum' considerably increased over time (sampling time [repeated]: $\left.\chi_{4}^{2}=116.03, P<0.001\right)$. Although a significant year effect was detected $\left(\chi_{1}^{2}=93.50, P<0.001\right)$, no significant interaction was present between sampling time and year reflecting the consistency of the observed pattern across both years $\left(\chi_{4}^{2}=8.03, P=0.090\right)$. As such, 42.9 and $11.4 \%$ of the tubers that were infested $4 \mathrm{DBH}$ tested positive for ' $\mathrm{Ca}$. L. solanacearum', after the simulated retail chain movement period, in 2013 and 2014, respectively (Fig. 3A and B). In the $10-\mathrm{DBH}$ treatment, ' $\mathrm{Ca}$. L. solanacearum' was detectable in $87.5 \%$ (2013) and 60.6\% (2014) of the tubers following the simulated retail chain movement period. Similar to the prestorage estimates, the effect of year was mostly observed in the 14-DBH treatment; 100 and $66.7 \%$ of the infested tubers tested positive for the presence of ' $\mathrm{Ca}$. L. solanacearum' after storage in 2013 and 2014, respectively (Fig. 3A and B).
Postharvest changes in ' $\mathrm{Ca}$. L. solanacearum' titer in relation to time of psyllid infestation. Overall, a significant increase in ' $\mathrm{Ca}$. L. solanacearum' titer was observed throughout the storage process (GLMM: $\left.F_{4,1018}=410.08, P<0.001\right)$. Significant effects of year $\left(F_{1,1018}=7.33, P=0.007\right)$ and treatment $\left(F_{2,1018}=18.52, P<\right.$ $0.001)$ were detected.

Relative changes in 'C $\mathrm{C}$. L. solanacearum' titer (' $\mathrm{Ca}$. L. solanacearum' $\left[\left(\chi, \chi_{\text {ref }}\right]\right)$ were also compared within every stage of storage (Table 1). 'Ca. L. solanacearum' $\left(\chi, \chi_{\text {ref }}\right)$ during wound healing was highly influenced by the time of infestation in the field (GLMM: $F_{1,207}=13.23, P<0.001$; Table 1$)$. Because none of the $4-\mathrm{DBH}$ tubers tested positive at harvest or at the end of the wound-healing stage, this infestation treatment was not included in the wound-healing stage analysis. The significant effect of infestation treatment was due to a greater ' $\mathrm{Ca}$. L. solanacearum' titer increase in 14-DBH tubers than the 10-DBH tubers (Table 1). Although year effect was present, the pattern of variation was consistent between 2013 and 2014 trials, as revealed by a nonsignificant year-infestation treatment interaction (Table 1).

' $C a$. L. solanacearum' $\left(\chi, \chi_{\mathrm{ref}}\right)$ was not affected by the time of infestation treatment during temperature ramping down (Table 1). However, pairwise comparisons revealed that ' $\mathrm{Ca}$. L. solanacearum' $\left(\chi, \chi_{\text {ref }}\right)$ in tubers infested $14 \mathrm{DBH}$ was greater than those observed in 10-DBH infestation treatments (Bonferroni LSD, $P=0.031$ ). The significant year effect persisted at this stage $(P=0.009)$; however, again, no interaction between year and infestation treatment was detected, reflecting the consistency of the observed pattern across both years of the study (Table 1).

At the holding stage (holding temperature $=7.2^{\circ} \mathrm{C}$ ), although no significant difference was detected among the infestation treatments, 'Ca. L. solanacearum' $\left(\chi, \chi_{\text {ref }}\right)$ exhibited a different pattern, because the 14-DBH treatment was relatively lower compared with $10 \mathrm{DBH}$ treatment (Table 1). No significant effects of year and year-infestation treatment were present at this stage (Table 1).

Variations in ' $\mathrm{Ca}$. L. solanacearum' titer among infestation treatments were statistically significantly different after storage and during

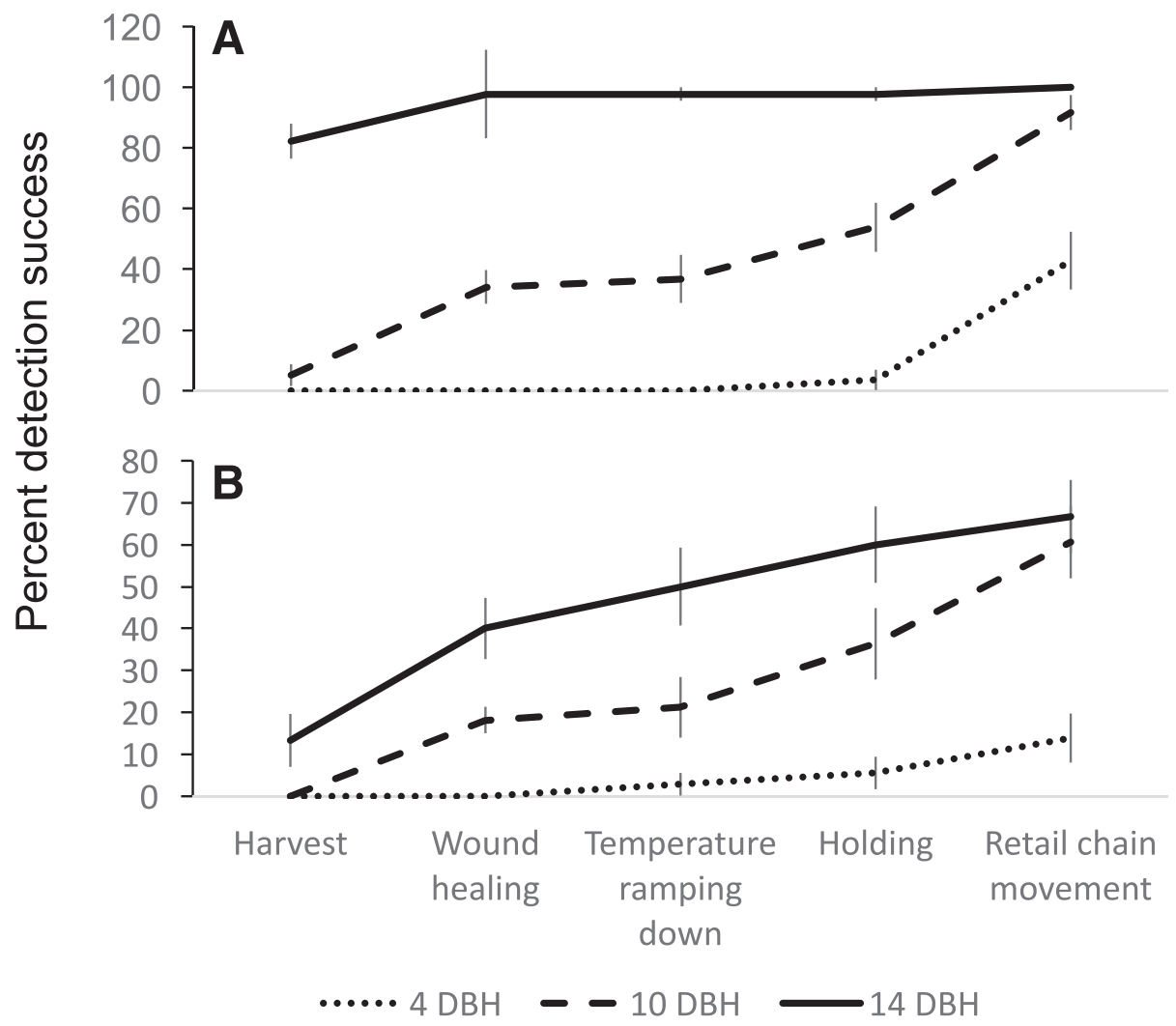

Fig. 3. Overall 'Candidatus Liberibacter solanacearum' detection success throughout different stages of storage, in tubers infected 14, 10, and 4 days before harvest (DBH) during A, 2013 and B, 2014. Error bars represent standard errors across plant replicates. 
the simulated retail chain movement (Table 1), with ' $C a$. L. solanacearum' $\left(\chi, \chi_{\text {ref }}\right)$ being significantly higher in the 10- than the 14-DBH treatment (Bonferroni LSD, $P=0.02$ ).

Variations in symptom severity. The symptom expression was significantly lower in 2014 than in the 2013 season, as detected by Mann-Whitney $(Z=-14.5, P<0.001)$; as such, results were analyzed independently for each year. In both years, significant differences in symptom severities were detected (Kruskal-Wallis: 2013, $\chi_{3}^{2}=93.07$, $\left.P<0.001 ; 2014, \chi_{3}^{2}=28.93, P<0.001\right)$, with $14 \mathrm{DBH}$ exhibiting the highest degree of symptom expression followed by $10 \mathrm{DBH}$ (Fig. 4A and $B)$. With the exception of three individual 4-DBH tubers with mild ZC symptoms, 4-DBH tubers and noninfected controls remained asymptomatic after storage (Fig. 4A and B).

Symptom severities and ' $\mathrm{Ca}$. L. solanacearum' titer were positively correlated in both $10-\mathrm{DBH}\left(r_{s}=0.361, P=0.003\right)$ and $14-\mathrm{DBH}$ $\left(r_{s}=0.445, P<0.001\right)$ treatments.

Changes in phenolic compounds in relation to the time of psyllid infestation. Activity levels of the 10 evaluated phenolic compounds after cold storage were highly influenced by the time of infestation in the field (MANCOVA: Pillai's Trace, $F_{30,300}=$ $3.69, P<0.001)$. With the exception of flavanol methyl glucoside $\left(F_{3,119}=38.32, P=0.166\right)$, all of the remaining nine evaluated phenolic compounds showed significant variation among the four infestation treatments, which included control plants $(P<0.028)$.

Relative changes in phenolic compound concentrations [phenol $\left.\left(\chi, \chi_{\text {ref }}\right)\right]$ between the start of the temperature ramping down and the end of cold storage were also influenced by infestation treatment (MANCOVA: Pillai's Trace, $F_{30,333}=4.29, P<0.001$; Table 2). With the exception of flavonoid glycoside $\left(F_{3,118}=0.651, P=\right.$ $0.584)$, flavanol methyl glucoside $\left(F_{3,118}=1.31, P=0.276\right)$, and protocatechuic acid hexoside $\left(F_{3,118}=1.77, P=0.156\right)$, the remaining seven evaluated phenolic compounds showed significant variation among the four infestation treatments $(P<0.015)$.

Changes in chlorogenic acid derivatives $(P<0.05)$ and cryptochlorogenic acid derivatives $(P<0.009)$ were significantly and positively correlated with changes in ' $\mathrm{Ca}$. L. solanacearum' titer in the

Table 1. Variation in the average relative changes in 'Candidatus Liberibacter solanacearum' titer ('Candidatus Liberibacter solanacearum' $\left.\left[\chi, \chi_{\text {ref }}\right]\right)^{\mathrm{y}}$

\begin{tabular}{|c|c|c|c|c|c|c|c|c|c|}
\hline \multirow[b]{2}{*}{ Storage procedure } & \multicolumn{3}{|c|}{$\begin{array}{l}\text { Mean relative ' } C a \text {. L. solanacearum' } \\
\text { titer change }(95 \% \text { confidence Interval) }\end{array}$} & \multicolumn{2}{|c|}{ Infestation treatment } & \multicolumn{2}{|l|}{ Year } & \multicolumn{2}{|c|}{$\begin{array}{l}\text { Year-infestation } \\
\text { treatment }\end{array}$} \\
\hline & $4 \mathrm{DBH}$ & $10 \mathrm{DBH}$ & 14 DBH & F (DF1, DF2) & $P$ value & F (DF1, DF2) & $P$ value & F (DF1, DF2) & $P$ value \\
\hline Wound healing $\mathrm{z}$ & N/A & $0.39(0.34)$ & $1.71(0.47)$ & $13.22(1,207)$ & $<0.001$ & $10.49(1,207)$ & 0.001 & $2.25(1,205)$ & 0.135 \\
\hline Temperature ramping down & $0.04(0.06)$ & $0.27(0.23)$ & $0.86(0.51)$ & $2.86(2,205)$ & 0.059 & $7.01(2,205)$ & 0.009 & $0.975(1,203)$ & 0.325 \\
\hline Holding & $0.01(0.03)$ & $0.56(0.36)$ & $0.14(0.24)$ & $1.81(2,205)$ & 0.167 & $1.97(1,205)$ & 0.162 & $0.006(2,203)$ & 0.994 \\
\hline Retail chain movement & $0.68(0.42)$ & $1.49(0.63)$ & $0.38(0.112)$ & $4.30(2,180)$ & 0.015 & $1.25(1,180)$ & 0.265 & $0.809(2,178)$ & 0.447 \\
\hline
\end{tabular}

y $\mathrm{DBH}=$ days before harvest and N/A = not applicable. Significant comparisons are highlighted bold.

${ }^{\mathrm{z}}$ Analysis at this stage excludes the 4-DBH treatment.

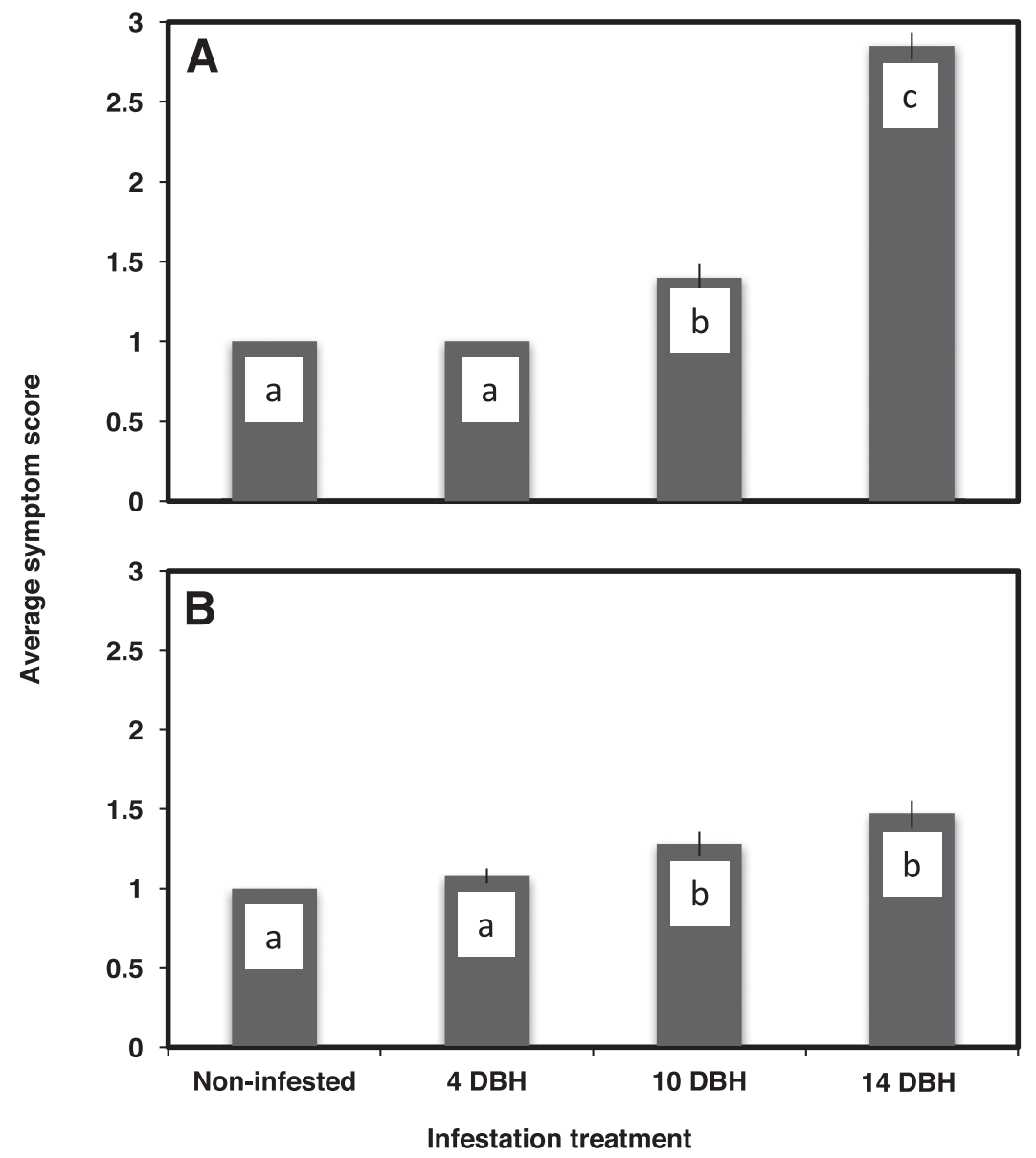

Fig. 4. Average symptom severity score in tubers infested 14,10 , or 4 days before harvest (DBH) as well as the noninfested controls. Error bars represent confidence interval (95\% COI) in A, 2013 and B, 2014. No significant symptom expression was detected in 4 DBH treatment in either year. 
10-DBH treatment (Table 3). In the 14-DBH treatment, cryptochlorogenic acid (one derivative) was the only component which was negatively correlated with relative changes in ' $\mathrm{Ca}$. L. solanacearum' (Table 3).

Spearman rank correlations revealed that ZC symptom severity was significantly positively correlated with concentrations of all 10 evaluated phenolic compounds (all $P<0.039$ ).

\section{Discussion}

The present study was set to evaluate, for the first time, changes in ' $C a$. L. solanacearum' titer throughout various stages of commercial storage process, each with different temperature requirements. The impact of ' $\mathrm{Ca}$. L. solanacearum' on tuber quality was also measured with respect to symptom severity, as well as changes in phenolic compounds during the storage process. Although the study focused on the infections that occurred within a 2-week time window prior to harvest, significant differences in frequencies of ' $\mathrm{Ca}$. L. solanacearum' detection, ' $\mathrm{Ca}$. L. solanacearum' titer development, phenolic activity levels, and symptom severity were detected across the infestation treatments. The present study also provided the first experimental report of ' $\mathrm{Ca}$. L. solanacearum' detection in tubers from plants that were infested with bacteriliferous potato psyllids only $4 \mathrm{DBH}$.

Only in the 14-DBH treatment did a substantial proportion of the tubers test positive for ' $\mathrm{Ca}$. L. solanacearum' at harvest. However, generally, a significant increase in the percentage of ' $C a$. L. solanacearum'-positive tubers was detected throughout the storage process and across all of the three infestation treatments. This was indicative of the presence of small quantities of ' $\mathrm{Ca}$. L. solanacearum' in tubers infested 4,10 , and even $14 \mathrm{DBH}$, which would be undetectable, immediately following harvest, by qPCR. As ' $\mathrm{Ca}$. L. solanacearum' continues to develop in the tuber throughout the postharvest process, a considerable percentage of tubers, previously determined to be ' $\mathrm{C} a$. L. solanacearum' negative, are expected to test positive after storage and following the simulated market chain movement. Another significant finding was that the pathogen could indeed translocate from an infected leaf to tuber tissue within at least 4 days, a result that is different from conclusions of an earlier study by Levy and colleagues (2011), who suggested that it would take a week for ' $\mathrm{Ca}$. L. solanacearum' to translocate into tubers. Further studies are warranted to investigate whether the tubers from later infestations (i.e., a day or two before harvest and vine-kill) would test positive for ' $\mathrm{Ca}$. L. solanacearum' following commercial storage. Infections occurring 1 or $2 \mathrm{DBH}$, however, are not expected to have a significant impact on tuber quality (see below).

Overall, a greater titer increase over time in storage was detectable in tubers infested $14 \mathrm{DBH}$ compared with those of 4- and 10-DBH treatments. This observation was similar to results from previous studies reporting a continuous increase in ' $\mathrm{Ca}$. L. solanacearum' titer in tubers infected 14 and $7 \mathrm{DBH}$ but held at a constant temperature after harvest (Rashed et al. 2015). In the present study, however, tubers were put through postharvest storage conditions similar to those recommended by the potato industry, exposing tubers to a varying temperature regimen. Although repeated tuber sampling may make decoupling the effects of infection duration and those of specific stages of storage on pathogen development difficult, our approach permitted us to compare relative changes in ' $\mathrm{Ca}$. L. solanacearum' titer, in relation to the time of infestation, within every storage step. Relative changes in ' $\mathrm{Ca}$. L. solanacearum' titer were significantly higher for $14 \mathrm{DBH}$ tubers during the wound-healing period; more specifically, between harvest and the start of temperature ramping down. Although a similar pattern persisted through temperature ramping down, the observed effect at this stage was only of borderline significance $(P=0.059)$. However, pathogen development at the holding temperature of $7.2^{\circ} \mathrm{C}$ started to show a different pattern; changes in ' $\mathrm{Ca}$. L. solanacearum' titer in tubers from the 14-DBH treatment were relatively but not significantly less than those of the 10-DBH treatment. During the simulated retail chain movement stage, changes in ' $\mathrm{Ca}$. L. solanacearum' titer in the 14-DBH treatment were significantly less than in the $10-\mathrm{DBH}$ and relatively lower than in

Table 2. Average relative changes in phenolic concentrations (phenol $\left[\chi, \chi_{\text {ref }}\right]$; nontransformed) between the start of temperature ramping down and the end of cold storage ${ }^{\mathrm{z}}$

\begin{tabular}{|c|c|c|c|c|}
\hline \multirow[b]{2}{*}{ Phenolic compound } & \multicolumn{4}{|c|}{ Concentration ( $\mu \mathrm{g} / \mathrm{g}$ fresh weight) } \\
\hline & Noninfested & 4 DBH & $10 \mathrm{DBH}$ & $14 \mathrm{DBH}$ \\
\hline Protocatechuic acid hexoside & $0.96(0.01) \mathrm{a}$ & $0.81(0.08) \mathrm{a}$ & $0.82(0.06) \mathrm{a}$ & $0.94(0.01) \mathrm{a}$ \\
\hline Flavonoid glycoside 1 & $7.02(0.29) \mathrm{ab}$ & $10.98(5.42) \mathrm{a}$ & $21.69(7.64) \mathrm{ab}$ & $66.06(47.58) b$ \\
\hline Flavonoid glycoside 2 & $16.25(7.10) \mathrm{ab}$ & $19.68(5.69) \mathrm{a}$ & $27.50(8.44) a b$ & $47.41(9.73) b$ \\
\hline Flavonoid glycoside 3 & $118.45(45.64) \mathrm{a}$ & $46.51(28.40) \mathrm{ab}$ & $61.15(17.78) b c$ & $210.24(35.74) \mathrm{c}$ \\
\hline Flavonoid glycoside 4 & $0.88(0.08) \mathrm{a}$ & $0.65(0.18) \mathrm{a}$ & $0.82(0.08) \mathrm{a}$ & $0.78(0.08)$ a \\
\hline Flavanol methyl ester glucoside & $18.22(5.58) \mathrm{a}$ & $11.21(2.39) \mathrm{a}$ & $11.28(1.95) \mathrm{a}$ & $17.89(4.51) \mathrm{a}$ \\
\hline Chlorogenic acid 1 & $17.89(4.52) \mathrm{a}$ & $12.45(4.12) \mathrm{a}$ & $6.16(1.87) \mathrm{a}$ & $22.84(8.46) \mathrm{b}$ \\
\hline Chlorogenic acid 2 & $8.61(5.06) \mathrm{a}$ & $2.96(1.65) \mathrm{a}$ & $5.98(1.96) \mathrm{a}$ & $22.27(3.08) b$ \\
\hline Cryptochlorogenic acid 1 & $7.17(1.35) \mathrm{a}$ & $7.24(3.23) \mathrm{a}$ & $11.35(3.26) \mathrm{a}$ & $53.01(9.70) \mathrm{b}$ \\
\hline Cryptochlorogenic acid 2 & $32.49(10.46) \mathrm{ac}$ & $16.46(8.72) b$ & $10.68(2.84) \mathrm{a}$ & $42.30(9.25) \mathrm{c}$ \\
\hline
\end{tabular}

${ }^{\mathrm{z}} \mathrm{DBH}=$ days before harvest. Different letters indicate Bonferroni-corrected statistical differences. Numbers in parentheses represent standard errors of mean relative changes in phenolic concentrations within each treatment.

Table 3. Relationships between relative changes in the evaluated phenolic compounds (phenol $\left.\left[\chi, \chi_{\mathrm{ref}}\right]\right)$ and 'Candidatus Liberibacter solanacearum' $\left(\chi, \chi_{\mathrm{ref}}\right)^{\mathrm{z}}$

\begin{tabular}{|c|c|c|c|c|c|c|c|c|c|}
\hline \multirow[b]{2}{*}{ Treatment } & \multicolumn{3}{|c|}{4 DBH } & \multicolumn{3}{|c|}{10 DBH } & \multicolumn{3}{|c|}{14 DBH } \\
\hline & $r$ & $N$ & $P$ value & $r$ & $N$ & $P$ value & $r$ & $N$ & $P$ value \\
\hline Protocatechuic acid hexoside & N/A & $\mathrm{d}$ & N/A & 0.136 & 38 & 0.406 & -0.083 & 44 & 0.593 \\
\hline Flavonoid glycoside 1 & N/A & 30 & N/A & 0.142 & 38 & 0.396 & -0.192 & 44 & 0.211 \\
\hline Flavonoid glycoside 2 & N/A & 30 & N/A & 0.033 & 38 & 0.843 & -0.158 & 44 & 0.309 \\
\hline Flavonoid glycoside 3 & N/A & 30 & N/A & 0.066 & 38 & 0.693 & -0.259 & 44 & 0.090 \\
\hline Flavonoid glycoside 4 & N/A & 30 & N/A & 0.018 & 38 & 0.912 & -0.227 & 44 & 0.139 \\
\hline Flavanol methyl ester glucoside & N/A & 30 & N/A & 0.062 & 38 & 0.712 & -0.283 & 44 & 0.062 \\
\hline Chlorogenic acid 1 & N/A & 30 & N/A & 0.320 & 38 & 0.050 & -0.286 & 44 & 0.059 \\
\hline Chlorogenic acid 2 & N/A & 30 & N/A & 0.346 & 38 & 0.033 & -0.208 & 44 & 0.176 \\
\hline Cryptochlorogenic acid 1 & N/A & 30 & N/A & 0.527 & 38 & 0.001 & -0.318 & 44 & 0.036 \\
\hline Cryptochlorogenic acid 2 & N/A & 30 & N/A & 0.427 & 38 & 0.008 & -0.106 & 44 & 0.492 \\
\hline
\end{tabular}

${ }^{\mathrm{z}} \mathrm{DBH}=$ days before harvest, $r=$ Pearson correlation regression coefficient, and N/A = not applicable. Significant relationships are highlighted bold. 
the 4-DBH treatment. This observed pattern suggests that enzymatic changes might be more pronounced in tubers that are expressing initial disease symptoms (i.e., tubers infected 2 weeks before harvest) (Rashed et al. 2014). The expression of defensive physiological responses in the 14-DBH tubers may limit ' $\mathrm{Ca}$. L. solanacearum' multiplication in this treatment, whereas enzymatic defense mechanisms may just be starting to develop and take effect in 4- and 10-DBH treatments. Indeed, the observed significant drop in relative ' $\mathrm{Ca}$. L. solanacearum' changes in the $14-\mathrm{DBH}$ in relation to the $10-\mathrm{DBH}$ treatment during the simulated retail chain movement stage supported the latter contention.

Subsequently, a question remains about whether changes in ' $\mathrm{Ca}$. L. solanacearum' titer of the late-season-infected potato tubers during storage would have significant impact on production quality by the time of processing or marketing. Because Russet Norkotah is predominantly a fresh-market variety, biochemical analyses were focused on phenolic contents, which are associated with discoloration of fresh tuber tissue (Navarre et al. 2009; Rashed et al. 2013; Wallis et al. 2012). Overall, activity levels of the evaluated phenolic compounds varied across infestation treatments. With the exception of three compounds, changes in all evaluated phenolics were significantly greater in the 14-DBH treatment than the noninfected, 4-DBH, or 10-DBH treatments (Table 2). The relationship between ZC symptom severity and concentration of phenolic compounds has previously been shown (Rashed et al. 2014), a conclusion that was also supported by the strong positive correlation between the two in the present study. $\mathrm{ZC}$ symptoms were nonexistent or minimal in 4-DBH tubers, which indicated that the quality effect on this infestation treatment was negligible, in spite of the fact that some tubers from this infestation treatment tested positive for ' $\mathrm{Ca}$. L. solanacearum' at the end of the simulated market chain movement stage. However, at this point, the present conclusion is only applicable to stored Russet Norkotah tubers. Further studies with processing varieties are needed to investigate the possibility of quality loss in fried products when infestations occur only days before harvest.

Variability in environmental conditions is expected to affect pathogenicity and Liberibacter-host interaction (Bové 2006; Lopes et al. 2009; Munyaneza et al. 2012). Because environmental variability is a common effect in field studies, the observed year effect in some of the analyses was not unexpected. Moreover, occasional malfunctioning of the irrigation system in the first year of this study was a stress factor that might have affected plant respiration and photosynthesis (King and Stark 2003), effects that also influence physiology of the harvested tubers (Olsen and Kleinkopf 2003). Regardless, the effect of year was controlled for in all statistical analyses. No significant interaction was detected between year and infestation treatments, which indicated the consistency of observed patterns between the 2 years of the study.

' $C a$. L. solanacearum' distribution within plant tissue is known to be an additional source of variability (Rashed et al. 2013; Wallis et al. 2014; Wen et al. 2009). To minimize the potential impact of heterogeneous distribution of ' $\mathrm{Ca}$. L. solanacearum' on the consistency of ' $\mathrm{Ca}$. L. solanacearum' detection and quantification over time, tuber samplings were conducted at the point of stolon attachment (stem end), at harvest, and from close proximity around the stem end over time. Although this approach would assist with consistency of findings, continuous sampling of the tubers may potentially manipulate plant respiration, tuber physiology (Strehmel et al. 2010), and defenserelated physiological responses (Constabel et al. 2000; Onkokesung et al. 2010; Rajendran et al. 2014). In spite of these possibilities, our approach was sensitive enough to detect significant increases in ' $\mathrm{Ca}$. L. solanacearum' detection success and titer over time.

For the first time, the effect of commercial postharvest storage on ' $C a$. L. solanacearum' development was studied. Because few or no visual symptoms are expected in tubers infected within 2 weeks of harvest (Rashed et al. 2014), the process of screening for ZCinfected tubers may fail to provide an acceptable estimate of infected tubers at harvest, especially where there is a high risk of late-season infestation by infective psyllids. Our results indicated that a considerable proportion of tubers that were infested within 14 days of harvest would test positive for ' $\mathrm{Ca}$. L. solanacearum' after storage. Moreover, poststorage screening for ' $\mathrm{Ca}$. L. solanacearum' will provide a more reliable assessment of infection status in the field.

Based on our findings, if psyllid populations are high at the end of the season, management practices are recommended until at least 4 days prior to green harvest to minimize the risk of late-season psyllid infestation on potato tuber quality. Studies are ongoing to evaluate whether the addition of vine-kill to agricultural practices could subject tubers infected $4 \mathrm{DBH}$ or later to considerable quality loss in areas with high risk of $\mathrm{ZC}$.

\section{Acknowledgments}

We thank our lab members for their help with different aspects of this project.

\section{Literature Cited}

Bové, J. M. 2006. Huanglongbing: A destructive, newly emerging, century-old disease of citrus. J. Plant Pathol. 88:7-37.

Buchman, J. L., Fisher, T. W., Sengoda, V. G., and Munyaneza, J. E. 2012. Zebra chip progression: From inoculation of potato plants with Liberibacter to development of disease symptoms in tubers. Am. J. Potato Res. 89:159-168.

Buchman, J. L., Sengoda, V. G., and Munyaneza, J. E. 2011. Vector transmission efficiency of Liberibacter by Bactericera cockerelli (Hemiptera: Triozidae) in zebra chip potato disease: Effects of psyllid life stage and inoculation access period. J. Econ. Entomol. 104:1486-1495.

Constabel, C. P., Yip, L., Patton, J. J., and Christopher, M. E. 2000. Polyphenol oxidase from hybrid poplar. Cloning and expression in response to wounding and herbivory. Plant Physiol. 124:285-295.

Crosslin, J. M., Olsen, N., and Nolte, P. 2012. First report of zebra chip disease and 'Candidatus Liberibacter solanacearum' on potatoes in Idaho. Plant Dis. 96:453.

Goolsby, J. A., Adamczyk, J., Bextine, B., Lin, D., Munyaneza, J. M., and Bester, G. 2007. Development of an IPM program for management of the potato psyllid to reduce incidence of zebra chip disorder in potatoes. Subtrop. Plant Sci. 59: 85-94.

Haapalainen, M. 2014. Biology and epidemics of Candidatus Liberibacter species, psyllid-transmitted plant-pathogenic bacteria. Ann. Appl. Biol. 165:172-198.

Hamm, P. B., Rondon, S. I., Crosslin, J. M., and Munyaneza, J. E. 2011. A new threat in the Columbia Basin of Oregon and Washington: Zebra Chip. Pages 1-5 in: Proc. 11th Annu. SCRI Zebra Chip Rep. Session. F. Workneh, A. Rashed, and C. M. Rush, eds.

Hansen, A. K., Trumble, J. T., Stouthamer, R., and Paine, T. D. 2008. A new huanglongbing species, 'Candidatus Liberibacter psyllaurous,' found to infect tomato and potato, is vectored by the psyllid Bactericera cockerelli (Sulc). Appl. Environ. Microbiol. 74:5862-5865.

Henne, D. C., Workneh, F., and Rush, C. M. 2010. Movement of Bactericera cockerelli (Heteroptera: Psyllidae) in relation to potato canopy structure, and effects on potato tuber weights. J. Econ. Entomol. 103:1524-1530.

King, B. A., and Stark, J. C. 2003. Irrigation management. Pages 285-307 in: Potato Production Systems. J. G. Stark and S. L. Love, eds. University of Idaho Agricultural Communications, Moscow, ID.

Kleinkopf, G. E., and Olsen, N. 2003. Storage management. Pages 363-381 in: Potato Production Systems. J. G. Stark and S. L. Love, eds. University of Idaho Agricultural Communications, Moscow, ID.

Levy, J., Ravindran, A., Gross, D., Tamborindeguy, C., and Pierson, E. 2011. Translocation of 'Candidatus Liberibacter solanacearum', the zebra chip pathogen, in potato and tomato. Phytopathology 101:1285-1291.

Li, W., Abad, J. A., French-Monar, R. D., Rascoe, J., Wen, A., Gudmestad, N. C. Secor, G. A., Lee, I. M., Duan, Y., and Levy, L. 2009. Multiplex real-time PCR for detection, identification and quantification of 'Candidatus Liberibacter solanacearum' in potato plants with zebra chip. J. Microbiol. Methods 78:59-65.

Li, W., Hartung, J. S., and Levy, L. 2006. Quantitative real-time PCR for detection and identification of 'Candidatus Liberibacter' species associated with citrus huanglongbing. J. Microbiol. Methods 66:104-115.

Liefting, L. W., Perez-Egusquiza, Z. C., Clover, G. R. G., and Anderson, J. A. D. 2008. A new 'Candidatus Liberibacter' species in Solanum tuberosum in New Zealand. Plant Dis. 92:1474.

Lin, H., Lou, B., Glynn, J. M., Doddapaneni, H., Civerolo, E. L., Chen, C., Duan, Y., Zhou, L., and Vahling, C. M. 2011. The complete genome sequence of 'Candidatus Liberibacter solanacearum', the bacterium associated with potato zebra chip disease. PLoS One 6:e19135.

Lopes, S. A., Frare, G. F., Bertolini, E., Cambra, M., Fernandes, N. G., Ayres, A. J., Marin, D. R., and Bové, J. M. 2009. Liberibacters associated with citrus huanglongbing in Brazil: 'Candidatus Liberibacter asiaticus' is heat tolerant, ' $C a$. L. americanus' is heat sensitive. Plant Dis. 93:257-262.

Munyaneza, J. E. 2012. Zebra chip disease of potato: Biology, epidemiology, and management. Am. J. Potato Res. 89:329-350.

Munyaneza, J. E., Sengoda, V. G., Buchman, J. L., and Fisher, T. W. 2012. Effects of temperature on 'Candidatus Liberibacter solanacearum' and zebra chip potato disease symptom development. Plant Dis. 96:18-23.

Navarre, D. A., Shakya, R., Holden, J., and Crosslin, J. M. 2009. LC-MS analysis of phenolic compounds in tubers showing zebra chip symptoms. Am. J. Potato Res. 86:88-95. 
Nolte, P., Olsen, N., Wenninger, E. J., and Thornton, M. 2011. Zebra chip found in Idaho. Page 6 in: Proc. 11th Annu. SCRI Zebra Chip Rep. Session. F. Workneh, A. Rashed, and C. M. Rush, eds.

Olsen, N., and Kleinkopf, G. E. 2003. Physiological disorders. Pages 309-327 in: Potato Production Systems. J. G. Stark and S. L. Love, eds. University of Idaho Agricultural Communications, Moscow, ID.

Onkokesung, N., Galis, I., von Dahl, C. C., Matsuoka, K., Saluz, H. P., and Baldwin, I. T. 2010. Jasmonic acid and ethylene modulate local responses to wounding and simulated herbivory in Nicotiana attenuata leaves. Plant Physiol. 153:785-798.

Rajendran, S., Lin, I. W., Chen, M. J., Chen, C. Y., and Yeh, K. W. 2014. Differential activation of sporamin expression in response to abiotic mechanical wounding and biotic herbivore attack in the sweet potato. BMC Plant Biol. 14:112.

Rashed, A., Wallis, C. M., Paetzold, L., Workneh, F., and Rush, C. M. 2013. Zebra chip disease and potato biochemistry: Tuber physiological changes in response to 'Candidatus Liberibacter solanacearum' infection over time. Phytopathology 103:419-426.

Rashed, A., Workneh, F., Paetzold, L., Gray, J., and Rush, C. M. 2014. Zebra chip disease development in relation to plant age and time of 'Candidatus Liberibacter solanacearum' Infection. Plant Dis. 98:24-31.

Rashed, A., Workneh, F., Paetzold, L., and Rush, C. M. 2015. Emergence of 'Candidatus Liberibacter solanacearum'-infected seed potato in relation to the time of infection. Plant Dis. 99:274-280.

Rush, C. M., Workneh, F., and Rashed, A. 2015. Significance and epidemiological aspects of late-season infections in the management of potato zebra chip. Phytopathology 105:929-936.

Secor, G. A., and Rivera-Varas, V. V. 2004. Emerging diseases of cultivated potato and their impact on Latin America. (Suppl.) Rev. Latinoam. Papa 1:1-8.

Secor, G. A., Rivera-Varas, V. V., Abad, J. A., Lee, I. M., Clover, G. R. G., Liefting, L. W., Li, X., and De Boer, S. H. 2009. Association of 'Candidatus Liberibacter solanacearum' with zebra chip disease of potato established by graft and psyllid transmission, electron microscopy, and PCR. Plant Dis. 93: 574-583.
Strehmel, N., Praeger, U., Konig, C., Fehrle, I., Erban, A., Geyer, M., Kopka, J. and van Dongen, J. T. 2010. Time course effects on primary metabolism of potato (Solanum tuberosum) tuber tissue after mechanical impact. Postharvest Biol. Technol. 56:109-116.

Swisher, K. D., Munyaneza, J. E., and Crosslin, J. M. 2012. High resolution melting analysis of the cytochrome oxidase I gene identifies three haplotypes of the potato psyllid in the United States. Environ. Entomol. 41:1019-1028.

Teresani, G. R., Bertolini, E., Alfaro-Fernández, A., Martínez, C., Tanaka, F. A O., Kitajima, E. W., Roselló, M., Sanjuán, S., Ferrándiz, J. C., López, M. M. Cambra, M., and Font, M. I. 2014. Association of 'Candidatus Liberibacter solanacearum' with a vegetative disorder of celery in Spain and development of a real-time PCR method for its detection. Phytopathology 104:804-811.

Wallis, C. M., Chen, J., and Civerolo, E. L. 2012. Zebra chip-diseased potato tubers are characterized by increased levels of host phenolics, amino acids, and defense-related proteins. Physiol. Mol. Plant Pathol. 78:66-72.

Wallis, C. M., Rashed, A., Chen, J., Paetzold, L., Workneh, F., and Rush, C. M. 2015. Effects of potato-psyllid-vectored 'Candidatus Liberibacter solanacearum' infection on potato leaf and stem physiology. Phytopathology 105:189-198.

Wallis, C. M., Rashed, A., Paetzold, L., Workneh, F., and Rush, C. M. 2014 Similarities and differences in physiological responses to 'Candidatus Liberibacter solanacearum' infection among different potato cultivars. Phytopathology 104: 126-133.

Wen, A., Lin, H., and Gudmestad, N. C. 2012. Development of PCR assay using SSR primers for detection and genotyping of 'Candidatus Liberibacter solanacearum'. Pages 74-78 in: Proc. 11th Annu. SCRI Zebra Chip Rep. Session. F. Workneh, A. Rashed, and C. M. Rush eds. Fredric Printing, Aurora, CO.

Wen, A., Mallik, I., Alvarado, V. Y., Pasche, J. S., Wang, X., Li, W., Levy, L., Lin, H., Scholthof, H. B., Mirkov, T. E., Rush, C. M., and Gudmestad, N. C. 2009 Detection, distribution, and genetic variability of 'Candidatus Liberibacter' species associated with zebra chip complex disease of potato in North America. Plant Dis. 93:1102-1115. 